\title{
RAZVOJ STRUKTURE I MOGUĆNOST PRIRODNE OBNOVE U ŠUMSKOM REZERVATU "MEDVJEĐAK" UNUTAR N.P. PLITVIČKA JEZERA $^{1}$ \\ STRUCTURE DEVELOPMENT AND POSSIBILITY OF NATURAL REFORESTATION IN THE "MEDVJEĐAK" FOREST RESERVATION WITHIN THE PLITVICE LAKES NATIONAL PARK
}

\author{
Tomislav Dubravac ${ }^{1}$, Vlado Krejči ${ }^{1}$, Boris $\operatorname{Vrbek}^{1}$, Valentin Roth ${ }^{1}$, \\ Nikola Lukić ${ }^{2}$ Željko Galić ${ }^{2}$ \\ ${ }^{1}$ Šumarski institut Jastrebarsko; Odjel za ekologiju i uzgajanje šuma, Trnjanska 35, \\ Zagreb \\ ${ }^{2}$ Šumarski fakultet Sveučilišta u Zagrebu; Zavod za uređivanje šuma, Svetošimunska
} 25 , Zagreb

\begin{abstract}
The authors present investigation results on the structure development and possibility of natural reforestation of pure beech stands in a secondary beech virgin forest in the "Medveđak" forest reservation. The reservation was established in 1976 by the Jastrebarsko Forest Research Institute, Department of Forest Typology, on an area of 156.3 ha. Investigations were carried out in a natural stand of mountain beech forest with dead nettle (Lamio orvale-Fagetum sylvaticae Ht. 1938) on two permanent experimental plots covering 1 ha. The first plot was established by the Faculty of Forestry in 1980 and the second by the Forest Research Institute in 1998. Measurements were taken of basic estimation data, horizontal crown projections recorded, on the basis of which calculations were performed of the sum of crown projections per ha in absolute and relative size, soil not covered by crowns, mean projection and mean diameter of a crown. For purpose of monitoring the possible natural reforestation, records were taken of the structure and number of young growth, as well as of the shrub layer, on the area of $360 \mathrm{~m}^{2}$, and classified into height-age classes. Estimation of crown damage was performed according to a unique method prescribed by the International Cooperative Programme on Assessment and Monitoring of Air Pollution Effects on Forests (ICP Forests).
\end{abstract}

\footnotetext{
${ }^{1}$ Rad prezentiran na II simpoziju poljoprivrede, veterinarstva, šumarstva i biotehnologije sa međunarodnim učešćem Strategija razvoja domaće proizvodnje, 28 - 30 septembar/rujan 2004 Bihać
} 
Investigations carried out on both plots are the basis for long-term, multidisciplinary observation of the process of the natural course of development of the structural changes in virgin-type common beech stands, according to the scientific research programmes of the Forest Research Institute, Faculty of Forestry and the International Cooperative Programme on Assessment and Monitoring of Air Pollution Effects on Forests (ICP Forests). The investigations are also used for comparison during structural development in management forests.

Key words: stand structure, natural reforestation, young growth, crown-cover over soil, crown damage, diameter and height increment, soil, beech

\section{Uvod i dosadašnja istraživanja-Introduction and investigations up to now}

Bukove šume rasprostiru se na površini od 1100000 ha, što čini 56,5\% površine šuma u Republici Hrvatskoj. Čiste bukove šume rasprostiru se na 250000 ha, bukove šume s primiješanim hrastom kitnjakom na 700000 ha, a mješovite šume bukve i jele zauzimaju površinu od 165000 ha. Od ukupne površine bukovih šuma 85 $\%$ su šume visokog uzgojnog oblika (nastale iz sjemena), a preostalih $15 \%$ predstavljaju šume niskog uzgojnog oblika ili panjače. Prirodno pomlađivanje oplodnim sječama na malim površinama s duljim pomladnim razdobljem optimalan je način obnove ovih šuma, gdje uz odgovarajuću njegu šuma općekorisne i gospodarske funkcije dolaze do punog izražaja (Matić i dr. 1996). Na opravdanost primjene jednodobnog načina gospodarenja oplodnim sječama u čistim bukovim sastojinama ukazuju i najnovija istraživanja (Krejči i Dubravac, 2003).

Sve manje je površina na Zemlji gdje čovjek nije direktno ili indirektno utjecao na razvoj biljnog i životinjskog svijeta. Od šume se stoljećima bezobzirno uzimalo ne vodeći računa o tome da je ona ranjiva i da se može uništiti. U zadnje vrijeme čovjek je spoznao da je potrebno očuvati što više šumskih površina koje su zdrave i sposobne za regeneraciju. Radi razumijevanja razvoja prirodne vegetacije i dobivanja podataka za eventualne ispravke smjernica gospodarenja u ostalim dijelovima šuma počela su osnivanja šumskih rezervata. U šumskim rezervatima zabranjeno je svako iskorišćavanje drva kao i drugi zahvati gospodarenja. Ne smije se iskoristiti ni jedno stablo pa ni sušci ni izvale. Zabranjena je upotreba bilo prirodnih, bilo umjetnih gnojiva, kao i sredstva za zaštitu bilja. Ne smije se zasaditi ni jedna sadnica, ni sijati sjeme bilo koje biljke. Dozvoljeno je samo prikupljanje podataka šumarima, biolozima i ekolozima da bi se utvrdio razvoj šuma u prirodnim uvjetima (Lukić i Kružić, 1992).

U Hrvatskoj, kao rijetko gdje u Europi, najveći dio šuma zadržao je svoja prirodna obilježja, a bukove šume su na cijeloj površini prirodne. Mnoge od njih danas su prva generacija šuma koje su nastale prirodnim pomlađivanjem starih bukovih prašuma. 
Ostatke prirodnih bukovih prašuma nalazimo samo $u$ nepristupačnim $i$ neotvorenim predjelima (Hren: Ramino korito, 1972), ili tamo gdje su bile zakonom zaštićene (Cestar i dr. Čorkova uvala-Plitvička jezera 1983). S obzirom na stanje šuma i prijetnje od daljnje degradacije, prije više od pedeset godina, točnije 1949. godine, zbog zaštite ekosustava i prirodnih fenomena, posebice očuvanja hidrološkog sistema jezera, proglašen je Nacionalni park "Plitvička jezera". Gospodarenje se temeljilo na očuvanju njihovog zdravstvenog stanja i sposobnosti regeneracije. U tom nacionalnom parku su šumski ekosustavi jedan od temeljnih čimbenika. Njihova opstojnost i stabilnost imaju nesaglediv utjecaj na ostale ekosustave i fenomene.

Stručni i znanstveni interes privukli su mnoge šumarske znanstvenike da svojim istraživanjima pomognu opstojnosti šumskih ekosustava toga područja. Hren (1976) nakon provedenih tipoloških istraživanja zaključuje kako način gospodarenja koji se obavlja ne pogoduje pojavi mladog naraštaja, napose bukve. Klepac (1984) zastupa aktivnu zaštitu šuma, a 1994. godine predlaže ekološko uređivanje šuma s naglaskom kako treba omogućiti trajnu prirodnu obnovu šuma. Poštenjak i Gradečki (1994) u N.P. "Risnjak" traže odgovor na pitanje, treba li sastojine toga područja prepustiti isključivo prirodnom razvoju ili opreznim gospodarskim radnjama pomagati njihov daljnji tijek razvoja. Matić i dr. (1995) upućuju na pomaganje pozitivnih procesa uzgojnim zahvatima pomlađivanja i njege u sumskim zajednicama hrasta crnike N.P."Mljet". Krejči i Dubravac (2001) na dvije pokusne plohe, koje su dugi niz godina bez znatnijeg utjecaja čovjeka, u N.P. "Plitvička jezera" i "Paklenica" proučavaju stanje obnove čistih bukovih sastojina. Plohe imaju nagomilanu preveliku drvnu masu i jaku zastrtost tla krošnjama (96\%), što onemogućuje pojavnost i razvoj mladog naraštaja iz sjemena, te zaključuju kako šumskim ekosustavima nacionalnih parkova, da bi trajno obavljali namijenju im ulogu, ne odgovara pasivni način zaštite, što upućuje na nužnost uzgojnih zahvata u smislu usmjeravanja i pomaganja pozitivnih prirodnih procesa. Slične rezultate pokazuju i najnovija istraživanja šuma bukve i jele u Nacionalnom parku «Risnjak» (Dubravac, Benko i Čavlović 2003, Dubravac i Vuletić 2003). Autori zaključuju kako je unazad više desetljeća izostao priliv jele iz prirodnog pomlađivanja, što upućuje na jasan proces izmjene vrsta drveća.

S ciljem praćenja razvoja šuma u prirodnim uvjetima na području N.P. "Plitvička jezera", Cestar s grupom suradnika tadašnjeg Odjela za tipologiju šuma Šumarskog instituta Jastrebarsko, osniva četiri šumska rezervata površine 1.347 hektara i to: "Medveđak" (1976), "Čorkova uvala-Čudinka" (1977), "Kik-Visibaba" (1979) i šumski rezervat "Riječica-Javornik" (1981). Cilj osnivanja rezervata je bio prikazati tadašnje (nulto) stanje vegetacije tla, stadija razvitka strukturnih odnosa, proizvodnosti i kvalitete. Tom prilikom osniva čitav niz pokusnih ploha trajnoga karaktera u smislu praćenja strukturnih osobina sastojina. Upravo su ta istraživanja temelj utvrđivanja njihovog daljnjeg tijeka rasta $\mathrm{i}$ razvoja, a posebice stanja i mogućnosti obnove kao temeljnog cilja trajne samoobnovljivosti, opstanka i potrajnoga gospodarenja ovih šumskih ekosustava. 
Sukladno gore nevedenom, cilj istraživanja je proširivanje spoznaja o stanju strukture i mogućnostima prirodne obnove čistih bukovih sastojina u prirodnim uvjetima (bez utjecaja čovjeka) na području N.P. «Plitvička jezera», odnosno šumskog rezervata «Medveđak». Zatim, utvrđivanje sadašnjeg stanja strukture bukovih sastojina, te ukazivanje na smjer razvoja, opstanka i uloge bukovih sastojina u cilju održavanja biološke raznolikosti šuma N.P. "Plitvička jezera". Prvenstveno će se istražiti i brojčano (a zbog jasnoće i opisno) definirati osnovni strukurni pokazatelji, veličina i oblik krošanja, zastrtost tla te karakteristike tala kao važnih pokazatelja mogućnosti prirodne obnove sastojina. Naročita pozornost usmjeriti će se na pojavu mladog naraštaja uz utvrđivanje uvjeta prirodne obnove odnosno pomlađivanja u takvim prirodnim uvjetima. Također, jedan od ciljeva je i ukazivanje na stanje oštećenosti krošanja bukve, te usporedbe rezultata istraživanja s gospodarskim šumama.

\section{Područje istraživanja-Investigated area}

Istraživanja su obavljena u šumskom rezervatu «Medveđak» na dvije pokusne plohe u prirodnoj sastojini brdske bukove šume sa mrtvom koprivom (Lamio orvaleFagetum sylvaticae Ht. 1938), gdje je to i dominantna šumska zajednica (Cestar i dr. 1982), a izgled sastojine razvidan je na fotografiji 1. Rezervat je smješten unutar većeg šumskog kompleksa bukovih šuma, u sjeveroistočnom dijelu Nacionalnog parka «Plitvička jezera». Prema podacima (2) rezervat obuhvaća 3 odjela $(26,27$ i 61) s ukupnom površinom od 156,3 ha. Najviša točka rezervata je $875 \mathrm{~m}$, a najniža $580 \mathrm{~m}$ nad morem, na kojoj je smješetena pokusna ploha Šumarskog instituta Jastrebarsko. Plohe se nalaze na geološkoj podlozi vapnenca, a zastupljena su tri tipa tla u određenom postotnom omjeru. Na uzvišenim položajima i na grebenima pojavljuje se crnica na vapnencima $(10 \%)$, na strmim padinama smeđe tlo na vapnencu, plitko (20\%), na blažim padinama smeđe tlo na vapnencu, srednje duboko $(40 \%)$ te $u$ vrtačama lesivirano ili ilimerizirano tlo $(30 \%)$. Inklinacija je od $10^{\circ}$ do $25^{\circ}$. U jugoističnom najnižem dijelu rezervata nalaze se vrtače, odakle se teren izdiže prema sjeveroistoku do najviše točke te se ponovo preko grebena koji spaja Turčić i Tupi vrh, spušta prema sjeveru i sjeveroistoku. 


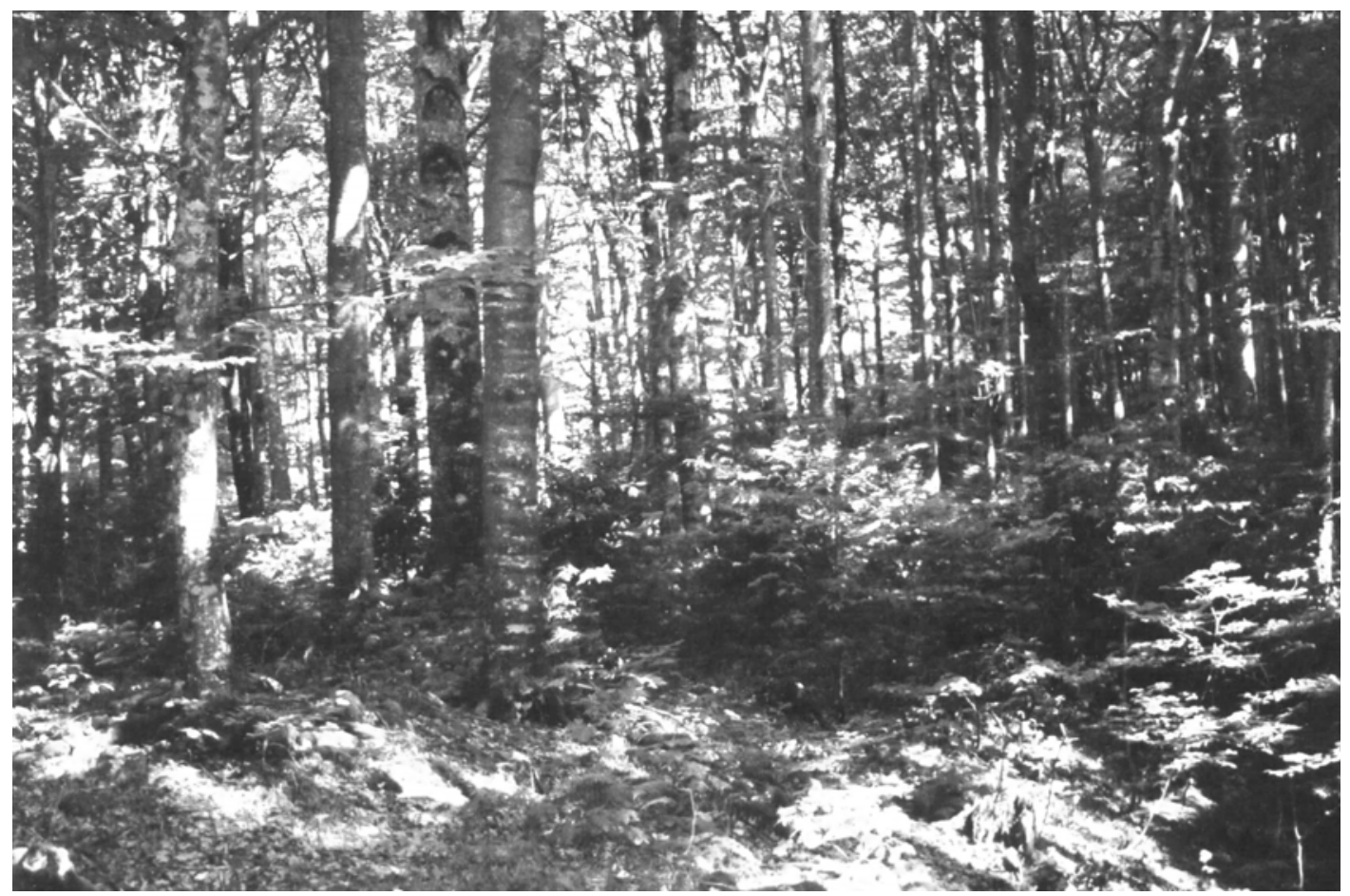

Fotografija 1. Izgled brdske bukove šume na pokusnoj plohi, Odjel 61 (Foto: T. Dubravac)

Photo 1. Mountain beech forest on the experimental plot Compertment 61 (Photo: T. Dubravac)

\section{Metoda istraživanja-Work method}

U okviru Projekta «Rast i razvoj šuma posebne namjene», Šumarskog instituta Jastrebarsko 1998. godine u 61. odjelu postavljena je stalna pokusna ploha veličine 100x100m po metodologiji Dubravac i Novotny (1992). Na plohi su sva stabla deblja od 7,5 cm obrojčana te su mjereni osnovni taksacijski podaci (prsni promjeri, visine stabala i dužine debala). U najhomogenijem dijelu plohe postavljena je podploha veličine $60 \times 60 \mathrm{~m}$. Svim stablima snimane su horizontalne projekcije krošanja temeljem kojih je izračunat zbroj projekcija krošanja po ha u apsolutnoj i relativnoj veličini, nezastrtost, srednja projekcija i srednji promjer krošnje. Iz tako snimljenih horizontalnih projekcija krošanja na terenu pristupilo se digitalizaciji krošanja $u$ programu MicroStation a datoteka je zatim transferirana u program AutoCAD 2000 format dwg zbog pojednostavljenog načina prikazivanja. Temeljem digitalnog modela i stvarnih mjerenih veličina na terenu (visina stabala i dužina debala, dužina i širina krošanja), izrađen je vertikalni profil sastojine u programu CorelDraw koji proporcionalno prikazuje odnos visine stabla, krošnje i debla. Kod izrade modela 
također se vodilo računa o prostornom rasporedu stabala i fenotipskim oblicima krošanja (Dubravac, 2002).

Zbog praćenja mogućnosti prirodne obnove na podplohi je snimana struktura i brojnost mladog naraštaja, kao i sloja grmlja na površini od $360 \mathrm{~m}^{2}$ (tri pruge veličine $2 \times 60 \mathrm{~m}$ ) te razvrstana $\mathrm{u}$ visinsko-starosne razrede.

Na plohi je obavljena i procjena oštećenosti krošanja prema jedinstvenoj metodi propisanoj od Međunarodnog Programa za procjenu i motrenje zračnog onečišćenja na šume (ICP Forests). Ključnu ulogu u Programu ima praćenje stanja oštećenosti šuma putem vizualne procjene oštećenosti krošanja. Hrvatska sudjeluje u Programu ICP-a od 1987. godine, a Šumarski institut Jastrebarsko je Nacionalni koordinacijski centar Programa. Najvažniji elementi procjene su: osutost (defolijacija) krošnje, gubitak boje (diskoloracija) asimilacijskih organa te lako prepoznatljivi (biotički i abiotički) uzroci štete. Ipak, defolijacija, glede njezina značaja kao indikatora stresa, ima prioritet. Praćenje oštećenosti je obavljeno i pet godina kasnije (2003. godine).

U okviru Projekta «Sto trajnih ploha Republike Hrvatske», Šumarski fakultet Sveučilišta u Zagrebu osniva 1980. godine stalnu pokusnu plohu u Odjelu 27 veličine 1 ha, na kojoj su sva stabla obrojčana. Godine 1988. ponovljena su sva mjerenja koja će biti prezentirana u ovome radu. U tijeku je ponovna izmjera na stalnoj pokusnoj plohi.

Pedološka analiza je obavljena otvaranjem pedoloških profila (za Odjel 61), detaljno istražena i dokumentirana (Fotografije 2., 3. i 4.), a uzorci su analizirani u laboratoriju Šumarskoga instituta, Jastrebarsko. Tom je prilikom određivana: reakcija tla primjenom staklene elektrode $\mathrm{u} \mathrm{H}_{2} \mathrm{O}$ i $\mathrm{M}-\mathrm{KCl}$, zatim kvantitativni sadržaj karbonata Scheiblerovim kalcimetrom u slučaju kada je $\mathrm{pH} \mathrm{u} \mathrm{H}_{2} \mathrm{O}$ bio veći od 7 , a sadržaj humusa određen je metodom Tjurina. Ukupni dušik određen je metodom po Kjeldahlu. Sadržaj fiziološki aktivnog fosfora i biljkama pristupačnog kalija određen je po metodi Al, tj. ekstrakcijom amonij-laktat-octenom kiselinom, mehanička analiza obavljena je pipet-metodom; priprema Na-pirofosfata. 


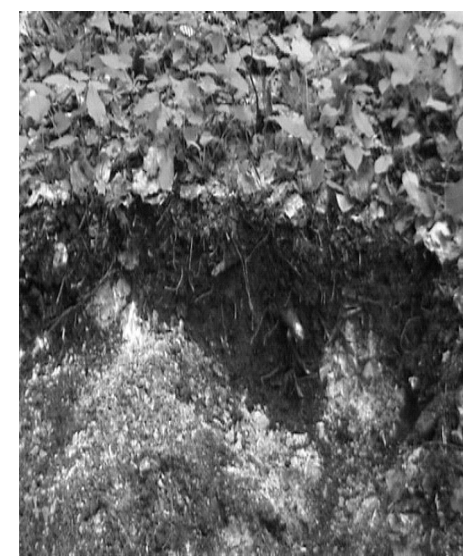

A-Crnica na vapnencu

Calcimelanosol

(Foto: B. Vrbek)

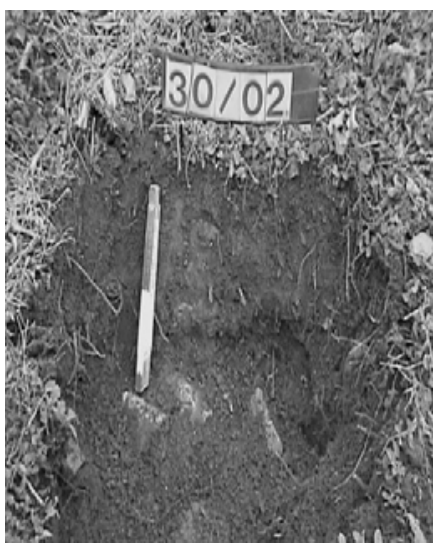

B-Smede tlo na vapnencu

Calcicambisol

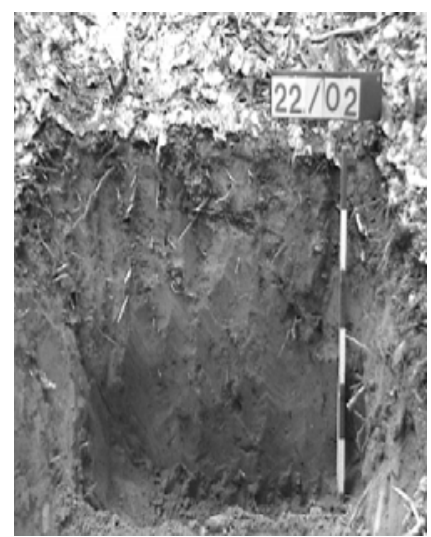

C-Lesivirano tlo u vrtači

Luvic siol on sinkhole

\section{Rezultati istraživanja s diskusijom-Results and discussion}

Kao što je već navedeno, istraživanja Šumarskog instituta Jastrebarsko su obavljena na pokusnoj plohi (Odjel 61) u brdskoj bukovoj šumi koja ima 301 stablo po ha, temeljnicu $42,67 \mathrm{~m}^{2}$ po ha te drvnu masu od $647,38 \mathrm{~m}^{3}$ po ha. Ovakva prevelika drvna masa, nagomilana na malom broju stabala, odraz je prirodnog tijeka razvoja ovih sastojina. Prosječne statističke vrijednosti aritmetički srednjeg sastojinskog stabla razvidne su u tablici 1. te zorno prikazane na slici 1. Slika prikazuje fenotipski izgled bukve u mjerilu i proporcionalan odnos visine stabla, dužine debla, širine i dužine krošnje. 


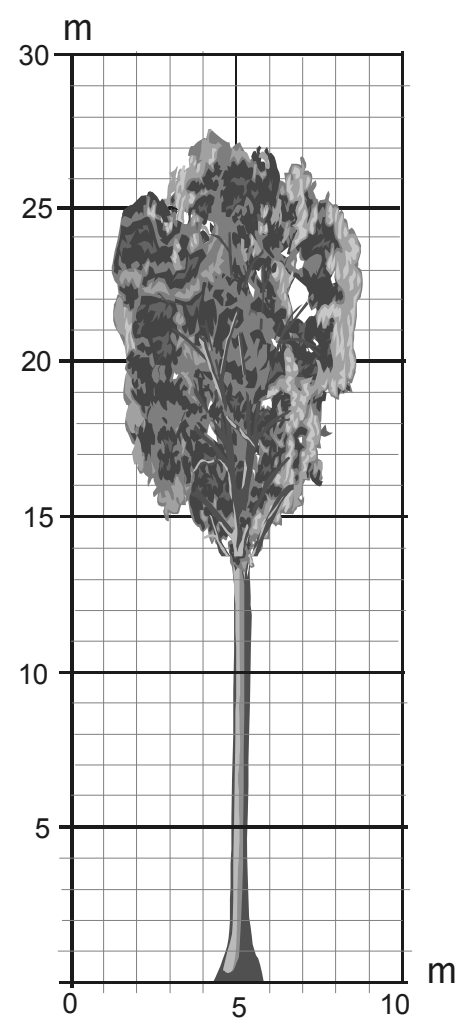

\begin{tabular}{|l|}
\hline$h=27,5 \mathrm{~m}$ \\
$h d=13,8 \mathrm{~m}$ \\
$d s=41,5 \mathrm{~cm}$ \\
$l k=13,7 \mathrm{~m}$ \\
$D=7,8 \mathrm{~m}$ \\
$P k=53,67 \mathrm{~m}^{2}$ \\
$V k=532,35 \mathrm{~m}^{3}$ \\
$g=0,14 \mathrm{~m}^{2}$ \\
$\mathrm{v}=2,15 \mathrm{~m}^{3}$ \\
Uzorak $=88$
\end{tabular}

Slika 1. Fenotipski izgled stabla bukve i prosječne vrijednosti srednjeg stabla na pokusnoj plohi, Odjel 61 (Slika u mjerilu)

Fig. 1 Phenotypical appearance of a beech tree and average values of a mean tree on the experimental plot,Compartment 61 (Figure to scale) 
Tablica 1. Osnovne statističke vrijednosti promatranih parametara stabala na plohi, Odjel 61

Table 1 Basic statistical values of observed tree parameters on the plot, Compartment 61

\begin{tabular}{|c|r|r|r|r|r|r|}
\hline Promatrani parametri & \multicolumn{5}{|c|}{ Statističke veličine-Statistical values } \\
\cline { 2 - 7 } Observed parameters & Arith.mean & Stand. dev. & Stand.eror. & \multicolumn{1}{|c|}{ Min. } & Maks. & Range \\
\hline \hline Prsni promjer-d $b h(d s) \mathrm{cm}$ & $\mathbf{4 1 , 4 9}$ & 17,458 & 1,861 & 11 & 84 & 73 \\
\hline Visina-Height $(h) \mathrm{m}$ & $\mathbf{2 7 , 4 6}$ & 5,485 & 0,588 & 14 & 36 & 22 \\
\hline $\begin{array}{c}\text { Dužina debla }(h d) \mathrm{m} \\
\text { Stem length }\end{array}$ & $\mathbf{1 3 , 7 8}$ & 3,601 & 0,386 & 4 & 20 & 16 \\
\hline $\begin{array}{c}\text { Dužina krošnje }(l k) \mathrm{m} \\
\text { Crown length }\end{array}$ & $\mathbf{1 3 , 7 1}$ & 3,541 & 0,379 & 5 & 22 & 17 \\
\hline $\begin{array}{c}\text { Promjer krošnje }(D) \mathrm{m} \\
\text { Crown diameter }\end{array}$ & $\mathbf{7 , 8 3}$ & 2,663 & 0,284 & 2,75 & 14,2 & 11,45 \\
\hline $\begin{array}{c}\text { Površina krošnje }(P k) \mathrm{m}^{2} \\
\text { Crown area }\end{array}$ & $\mathbf{5 3 , 6 7}$ & 35,092 & 3,741 & 5,94 & 158,36 & 152,42 \\
\hline $\begin{array}{c}\text { Volumen krošnje }(V k) \mathrm{m}^{3} \\
\text { Crown volume }\end{array}$ & $\mathbf{5 3 2 , 3 5}$ & 432,888 & 46,411 & 27,02 & 2264,59 & 2237,57 \\
\hline
\end{tabular}

Izmjera i stanje strukture te brojnosti i kvalitete mladog naraštaja na uzorku od $360 \mathrm{~m}^{2}$ (koja je dugi niz godina bez znatnijeg utjecaja čovjeka), razvidno je u Tablici 2. Stanje mladog naraštaja je loše. Naime, većina pomlatka je u visinskom razredu do $30 \mathrm{~cm} \mathrm{(43 \% )} \mathrm{i} \mathrm{do} 60 \mathrm{~cm}(39 \%)$, što čini $82 \%$ ukupnih jedinki, a zbog jake zastrtosti tla krošnjama od 96\% (Slika 2) upitnog je preživljenja. Nešto prisutniji mladi naraštaj gorskog javora te posebice grmlja ne ide u prilog prirodnoj obnovi bukve. Prema izmjeri širine krošanja iz digitalnog modela horizontalnih projekcija krošanja, uz pretpostavku da odumre stablo s najširom krošnjom koja iznosi 14,2 m (Tablica 1), otvorio bi se sklop $158,36 \mathrm{~m}^{2}$, što je nedovoljno za razvoj kvalitetnog naraštaja bukve, koja po svojoj biologiji zahtijeva obnovu na većim površinama. Izgled jednog takvog odumrlog stabla razvidan je na fotografiji 5 . 
Tablica 2. Broj ponika, pomlatka i mladika po hektaru, Odjel 61 (površina uzorka 360 $\left.\mathrm{m}^{2}\right)$

Table 2. Number of saplings, young growth and thicket per hectare, Compartment 61 (sample area $360 \mathrm{~m}^{2}$ )

\begin{tabular}{|c|c|r|r|r|}
\hline \multicolumn{2}{|c|}{$\begin{array}{l}\text { Visinsko-starosni } \\
\text { razred raslinja (cm) } \\
\text { Height-age class } \\
\text { of plants (cm) }\end{array}$} & \multicolumn{3}{|c|}{$\begin{array}{c}\text { Vrsta drveća-raslinja } \\
\text { Tree-types plants }\end{array}$} \\
\cline { 3 - 5 } & $\begin{array}{l}\text { Bukva } \\
\text { Beech }\end{array}$ & $\begin{array}{c}\text { Gorski } \\
\text { javor } \\
\text { Sycamore }\end{array}$ & $\begin{array}{c}\text { Grmlje } \\
\text { Shrubs }\end{array}$ \\
\hline $\begin{array}{l}\text { do 30 } \\
\text { up to 30 }\end{array}$ & Jednogod. - One year old & 28 & 28 & 2083 \\
\cline { 2 - 5 } & Višegod. - Several years old & 1500 & 1500 & 26083 \\
\hline Ukupno do 30-Total & $\mathbf{1 5 2 8}$ & $\mathbf{1 5 2 8}$ & $\mathbf{2 8 1 6 6}$ \\
\hline $31-60$ & 1389 & 1417 & 5500 \\
\hline $61-130$ & 555 & 555 & 361 \\
\hline $131-150$ & 28 & 28 & \\
\hline $151-200$ & 28 & 28 & \\
\hline $201-250$ & & & \\
\hline $251>$ & $\mathbf{3 5 2 8}$ & $\mathbf{3 5 5 6}$ & $\mathbf{3 4 0 2 7}$ \\
\hline
\end{tabular}

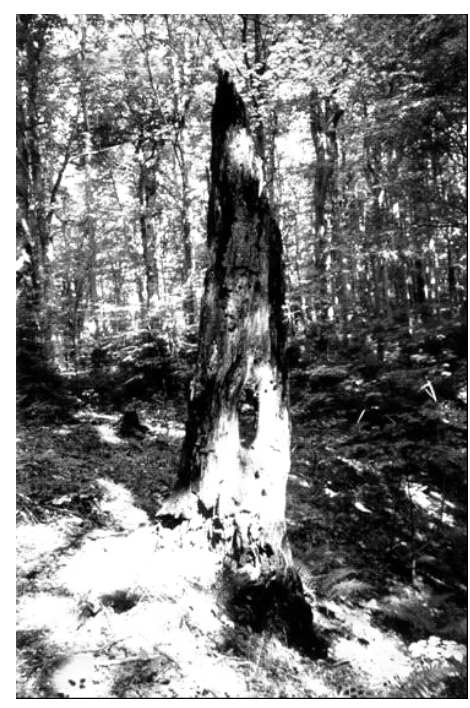

Fotografija 5. Odumrlo stablo bukve na pokusnoj plohi, odjel 61 (Foto: T. Dubravac) Photo 5. Dead beech tree on the experimental plot, Compartment 61 (Photo: T. Dubravac) 

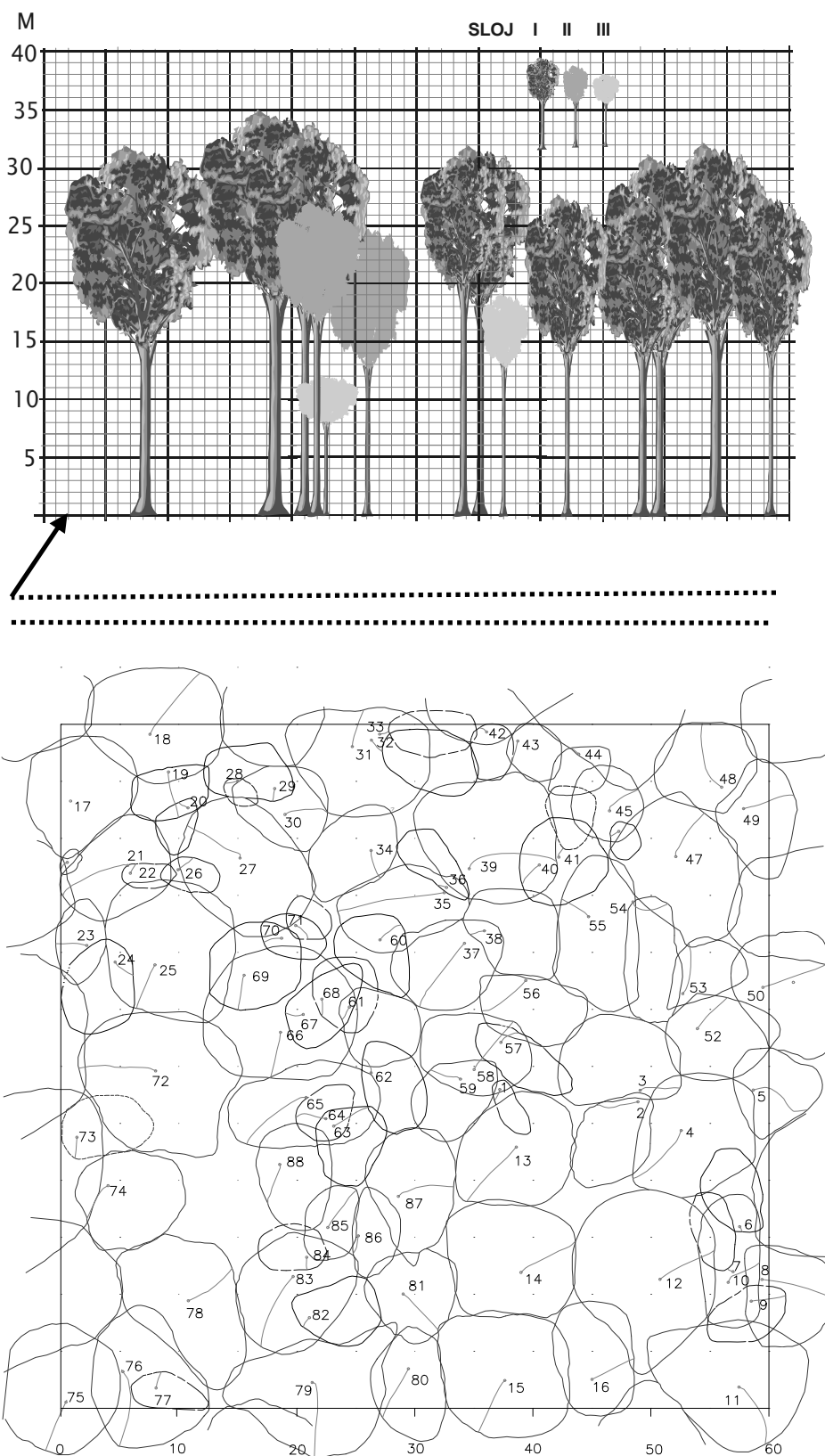

Slika 2. Digitalni model (AutoCAD 2000) projekcije krošanja po slojevima, prostorni raspored stabala i vertikalni profil sastojine

Fig. 2. Digital model (AutoCAD 2000) of crown projections by layers, spatial distribution of trees and vertical stand profile 
Na Slici 2. razvidni su rezultati istraživanja na primjeru digitalnog modela horizontalne projekcije krošanja po slojevima koji pokazuju preveliku zastrtost tla krošnjama (96\%), što je jedan od značajnih čimbenika koji utječe na mogućnost prirodne obnove. Većina stabala nalazi se u prvom sloju (65\%), dok je u drugom $(18 \%)$ i trećem sloju (17\%) podjednak broj stabala. Treba naglasiti kako su stabla u trećem sloju odraz prirodnog odumiranja stabala uvjetovana već navedenom prevelikom zastrtošću tla od $96 \%$ i bez utjecaja gospodarenja. Zbroj horizontalnih projekcija krošanja svih stabala debljih od $7,5 \mathrm{~cm}$, po hektaru površine iznosi 15 $743,92 \mathrm{~m}^{2}$ ili $157 \%$ dok je ukupni volumen krošanja $156153,85 \mathrm{~m}^{3}$. Nezastrto je svega $4 \%$ obrasle šumske površine. Srednji promjer krošnje iznosi 7,83 m, projekcija krošnje srednjeg stabla $53,67 \mathrm{~m}^{2}$, a srednji volumen krošnje je $532,35 \mathrm{~m}^{3}$. Na istoj slici razvidan je i vertikalni profil sastojine koji proporcionalno prikazuje odnos visine stabla, krošnje i debla, kao i razmaka stabala. Vidimo kako se radi o horizontalnom sklopu što ukazuje na jednodobnost sastojine. Sklop krošanja i njegova struktura je izrazito bitan čimbenik ekoloških uvjeta u sastojini (svjetlo), tzv. «sastojinske klime», topline $\mathrm{i}$ vlage te mineralizacije i humifikacije organske tvari u tlu) te naročito uvjeta pomlađivanja.

Oštećenost krošanja na pokusnoj plohi za razdoblje motrenja 1998. i 2003. godina te usporedba sa prosječnim vrijednostima u Republici Hrvatskoj u 2003. godini (Izvor: Šumarski institut, Jastrebarsko) razvidna je na slici 3., dok je prosječno stanje značajne oštećenosti krošanja bukve (stabla osutosti krošnje više od 25\%) u Republici Hrvatskoj za zadnjih 9 godina motrenja prikazano na slici 4. Rezultati pokazuju kako je 1998. godine na plohi zabilježeno 5,6\% značajno oštećenih stabala dok je takvih stabala u drugom motrenju (2003. godine) bilo značajno više i to $17,1 \%$, što je tri puta više. Ovakav uvećani postotak značajno oštećenih stabala u 2003. godini, između ostalog, valja pripisati velikom udjelu stabala u trećem sloju (15 od procijenjenih 88 stabala), koja su tijekom svog prirodnog toka razvoja izlučena u sastojini, a gdje nije bilo nikakvih gospodarskih zahvata. Naime, sva stabla koja se nalaze u trećem sloju tijekom prve procjene (1998.) su dobila ocjenu 2 (osutost krošnje 26-60\%), dok su procjenom 2003. godine ocijenjena ocjenom 3 (oštećenost od 60 do 99\%), a čak šest stabala se potpuno osušilo (ocjena 4). Dakle, stabla su nakon pet godina usljed prirodnog izlučivanja i neprovedenih uzgojnih mjera praktički odumrla. Navedeni rezultati ukazuju kako kod procjene oštećenosti krošanja treba voditi računa o biološkom položaju stabala u sastojini te kako monitoring na ovakvim trajnim pokusnim plohama treba provoditi trajno kako ne bismo dobili krivu sliku o oštećenosti.

Iz slike 4. je razvidno kako se stanje značajne oštećenosti obične bukve u posljednjih 9 godina praćenja nije bitno mijenjalo, nego se koleblao ovisno o jakosti nepovoljnih ekoloških i bioloških čimbenika različite vrste te se značajna oštećenost kretala od 4,4 do $11,9 \%$, dok je bukva sa $9,5 \%$ u 2003. godini i dalje zadržala epitet najotpornije vrste drveća u Hrvatskoj. 


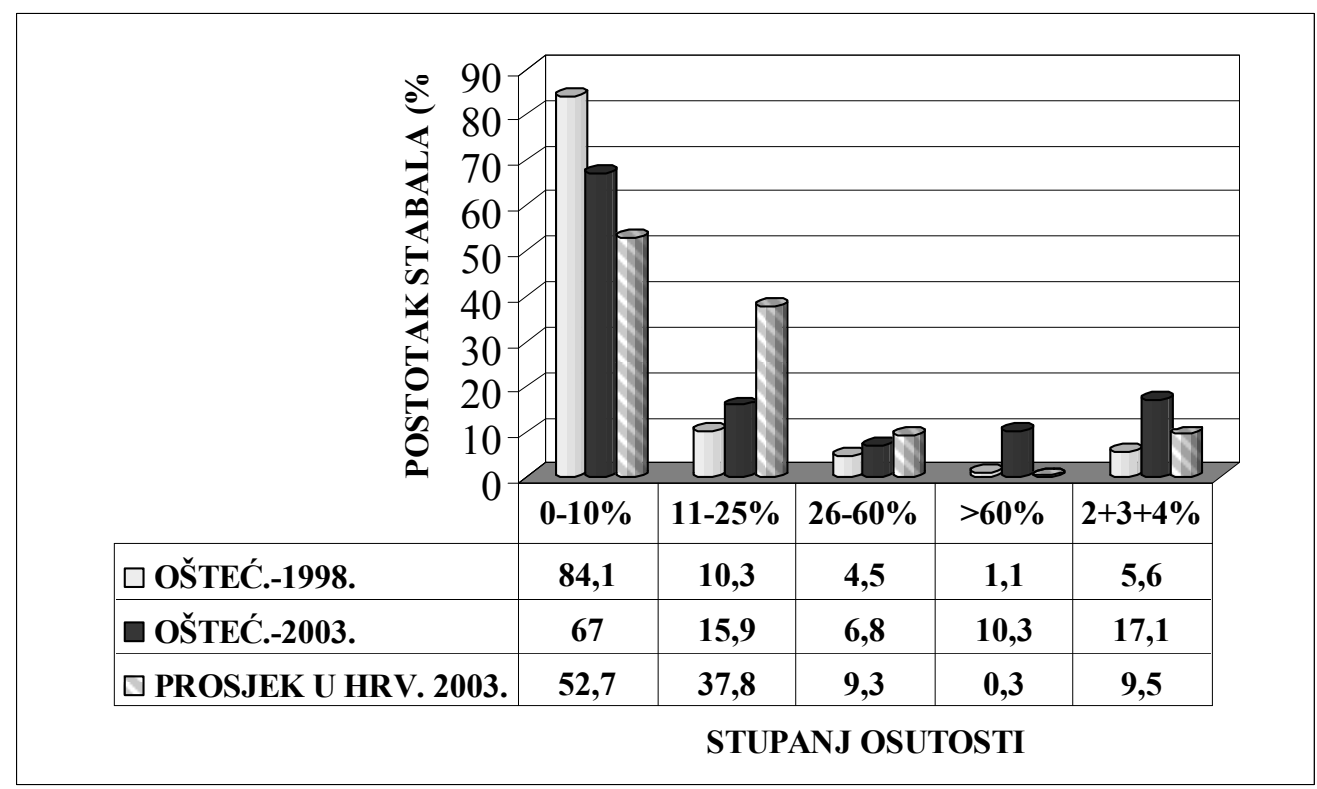

Slika 3. Oštećenost krošanja obične bukve na pokusnoj plohi, Odjel 61 Fig. 3. Crown damage of Common beech on the experimental plot, Compartment 61

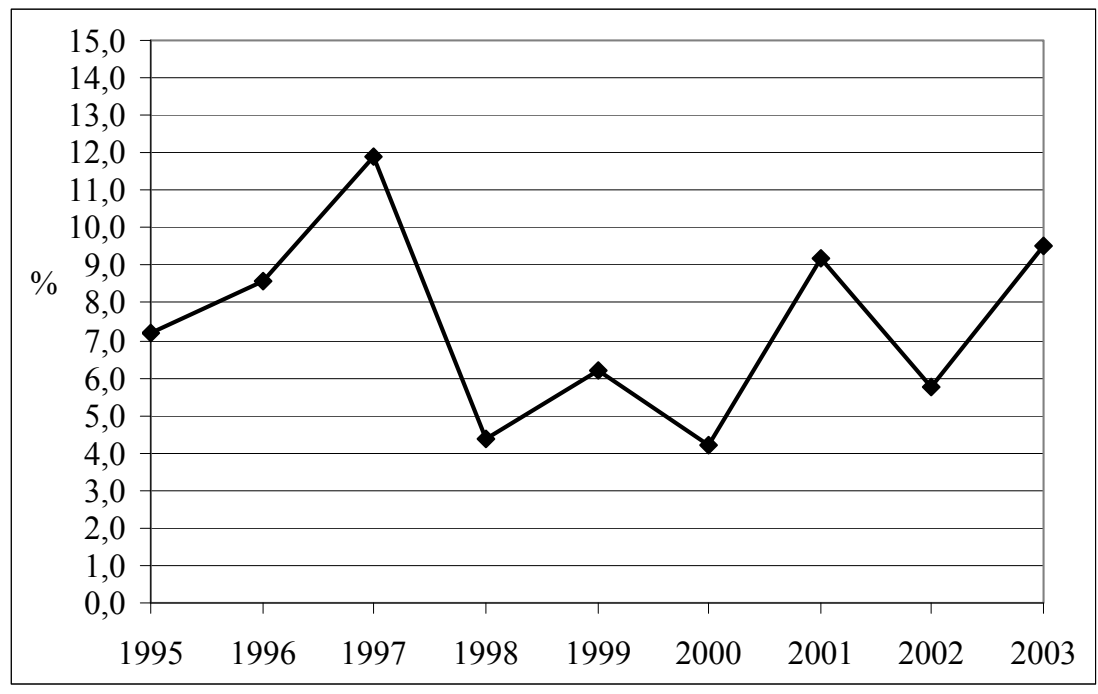

Slika4. Značajna oštećenost krošanja obične bukve u Hrvatskoj za period 1995-2003 (Izvor: Šumarski institut, Jastrebarsko)

Fig. 4. Considerable damage of Common beech crowns in Croatia for the period 1995.-2003. (Source: Forest Research Institute, Jastrebarsko) 
Kako je već navedeno u Metodi istraživanja, ovaj članak se bavi i rezultatima istraživanja na pokusnoj plohi koju je 1980. godine osnovao Šumarski fakultet Sveučilišta u Zagrebu, a rezultati strukture sastojine nultog stanja izmjere1980. i ponovne izmjere 1988. godine razvidni su u tablici 3.

Tablica 3. Strukturni elementi izmjere na plohi u Odjelu 27 (Lukić i Kružić 1992.) Table 3. Structural measurement elements on the plot in Compartment 27 (Lukić and Kružić 1992.)

\begin{tabular}{|c|c|c|c|}
\hline Distribucija prsnih promjera- $d b$ h distribution & $\begin{array}{c}\text { Izmjera-Measur } \\
1980 . \\
\end{array}$ & \begin{tabular}{c|c|} 
Sušci \\
Dead wood
\end{tabular} & $\begin{array}{c}\text { Izmjera-Measur } \\
1988 . \\
\end{array}$ \\
\hline 1. Broj stabala $\mathrm{N}$ & 447 & 29 & 418 \\
\hline 2. Temeljnica $\mathrm{G}\left(\mathrm{m}^{2}\right)$ & 42,37 & 1,99 & 45,53 \\
\hline 3. Volumen $\mathrm{V}\left(\mathrm{m}^{3}\right)$ & 424,64 & 20,59 & 485,26 \\
\hline 4. Promjer srednjeg plošnog stabla dg $(\mathrm{cm})$ & 34,7 & 29,5 & 37,2 \\
\hline 5. Srednji promjer $\mathrm{d}_{\mathrm{s}}(\mathrm{cm})$ & 31,9 & 25,2 & 34,6 \\
\hline 6. Stand. dev. promjera $s_{d}$ & 13,675 & 15,361 & 13,636 \\
\hline 7. Koeficijent skošenosti $\beta_{1}$ & 1,589 & - & 1,542 \\
\hline 8. Koeficijent spljoštenosti $\beta_{2}$ & 3,228 & - & 3,044 \\
\hline \multicolumn{4}{|c|}{$\begin{array}{l}\text { Distribucija visina i visinska krivulja (Mihajlova funkcija) } \\
\text { Distribution of heights and height curve (Mihajlov function) }\end{array}$} \\
\hline 9. Broj visina $\mathrm{n}$ & 118 & - & 79 \\
\hline 10. Srednja visina $\mathrm{h}(\mathrm{m})$ & 19,5 & - & 21,1 \\
\hline 11. Stand. dev. visina hs (m) & 4,438 & - & 3,093 \\
\hline 12. Koeficijent skošenosti $\beta_{1}$ & $-1,108$ & - & $-1,511$ \\
\hline 13. Koeficijent spljoštenosti $\beta_{2}$ & 2,058 & - & 3,327 \\
\hline 14. Reg. konstanta b0 & 27,104 & - & 26,909 \\
\hline 15. Reg. koeficijent $b_{1}$ & 13,452 & - & 10,322 \\
\hline 16. Stand. dev. logaritma regres. konst. $S_{b 0}$ & 0,038 & - & 0,038 \\
\hline 17. Stand dev. regres. koef. $S_{b 1}$ & 0,016 & - & 0,021 \\
\hline 18. Stand. dev. $\mathrm{S}_{\text {thr, } / \mathrm{d}}$ & 0,094 & - & 0,071 \\
\hline
\end{tabular}

Legend: 1. Number of trees, 2. Basal area, 3. Volume, 4. Diameter mean basal area tree, 5. Mean diameter, 6. Standard deviation of diameter, 7. Coefficient skewness $\beta_{1}$, 8. Coefficient kurtosis $\beta_{2}$, 9. Number of heights, 10. Mean height, 11. Stand. dev. and height, 12. Coefficient skewness $\beta_{1}$ 13. Coefficient kurtosis $\beta_{2}$, 14. Reg. const. $b_{o}, 15$. Reg. coefficient $b_{1}, 16$. Stand. dev. logarith. regress. const. $S_{b 0}$, 17. Stand dev. regess. coeff. $S_{b l}, 18$. Stand. dev. sinh/d 
Iz tablice 3 je razvidno da je distribucija promjera, a što nam pokazuju i koeficijenti skošenosti $\left(\beta_{1}\right)$ i spljoštenosti $\left(\beta_{2}\right)$, desne asimetrije i pozitivne spljoštenosti. To je inače karakteristika jednodobnih bukovih sastojina. Distribucija visina kod obje izmjere ukazuje na negativnu skošenost $\left(\beta_{1}=-1.108\right.$ i $\left.-1,511\right)$ i pozitivnu spljoštenost što također ukazuje na to da se radi o jednodobnoj sastojini obične bukve. Volumni prirast bukovih stabala za promatrani period iznosi $V_{1988}-V_{1980}$ $=60,62 \mathrm{~m}^{3}$, odnosno tečajni godišnji volumni prirast iznosi $i_{v}=7,58 \mathrm{~m}^{3}(1,56 \%)$. Prema istraživanjima (2) u ovom sastojinskom obliku na istom lokalitetu je tečajni godišnji volumni prirast $i_{v}=9,53 \mathrm{~m}^{3}(2,64 \%)$.

Na plohi je obavljeno utvrđivanje debljinskog i visinskog prirasta. Debljinski prirast utvrđen je kontrolnom metodom jer su bile poznate distribucije prsnih promjerana početku i na kraju periode. Krivulje izjednačenja prsnh promjera u oba slučaja su pravci.

Visinski prirast izračunat je na osnovi razlike izjednačenih visina stabala pri čemu su krivulje izjednačenja u oba slučaja parabole drugog reda. Također na 4 modelna stabla bukve, totalnom su analizom analizirani svi prirasti, a posebice debljinski prirast. Rezultati regresijske analize razvidni su u tablici 4.

Tablica 4. Regresijske analize visinskog i debljinskog prirasta u Odjelu 27 (Lukić i Kružić 1992.)

Table 4. Regression analyses of the height and diameter increment in Compartment 27 (Lukić and Kružić 1992.)

\begin{tabular}{|c|c|c|c|c|}
\hline \multirow{2}{*}{$\begin{array}{l}\text { Parametri } \\
\text { Parameters }\end{array}$} & \multicolumn{4}{|c|}{ Modeli-Models } \\
\hline & 1 & 2 & 3 & 4 \\
\hline $\mathbf{b}_{0}$ & 0,2347 & 0,2302 & 0,4364 & 0,3687 \\
\hline $\mathbf{S}_{\mathbf{b 0} \mathbf{0}}$ & 0,0001 & 0,0261 & 8,4207 & 14,1497 \\
\hline $\mathbf{b}_{1}$ & 0,0014 & 0,0023 & $-0,0064$ & $-0,0073$ \\
\hline $\mathbf{s}_{\mathrm{b} 1}$ & 0,0054 & 0,0006 & 1,1652 & 3,0270 \\
\hline $\mathbf{b}_{2}$ & - & - & 0,00005 & 0,0001 \\
\hline $\mathbf{s}_{\mathrm{b} 2}$ & - & - & 0,1777 & 0,6617 \\
\hline $\mathbf{s}_{\mathbf{x}, \mathbf{y}}$ & 0,057 & 0,080 & 0,065 & 0,084 \\
\hline $\mathbf{i}_{\mathbf{d}}$ & 0,282 & 0,324 & - & - \\
\hline $\mathbf{S}_{\mathbf{i d}}$ & 0,060 & 0,088 & - & - \\
\hline $\mathbf{i}_{\mathbf{h}}$ & - & - & 0,283 & 0,277 \\
\hline $\mathbf{s}_{\text {ih }}$ & - & - & 0,069 & 0,077 \\
\hline $\mathbf{n}$ & 830 & 69 & 69 & 69 \\
\hline \multicolumn{5}{|c|}{ 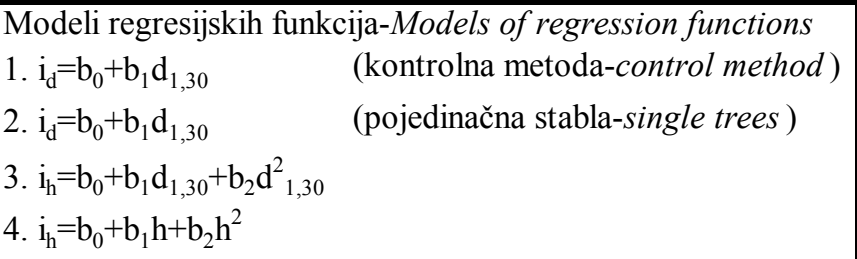 } \\
\hline
\end{tabular}


Dobiveni rezultati su ukazali da je trend debljinskog prirasta obične bukve manji nego što je uobičajeno za taj sastojinski oblik. Prema istraživanjima Schobera u Njemačkoj, u približno sličnim sastojinama obične bukve po strukturnim elementima i ostalim ekološkim karakteristikama, prirast je veći skoro dva puta (Schober, 1972).

Glavni tipovi tala, podtipovi, varijeteti i forme na istraživanom području prikazani su u tablici 5 , a srednje vrijednosti kemijskih i fizičkih analiza prikazane u tablici 6 .

Tablica 5. Popis pedosistematskih jedinica Table 5. List of pedosystematic units

\begin{tabular}{|c|c|c|c|}
\hline Tip-Type & Podtip-Sub-type & Varijetet-Variety & $\begin{array}{c}\text { Forma- } \\
\text { Form }\end{array}$ \\
\hline $\begin{array}{c}\text { Vapneno-dolomitna } \\
\text { crnica } \\
\text { (Kalkomelanosol) }\end{array}$ & $\begin{array}{c}\text { Organomineralna } \\
\text { Posmeđena }\end{array}$ & $\begin{array}{c}\text { Litična } \\
\text { Skeletno koluvijalna }\end{array}$ & - \\
\hline $\begin{array}{c}\text { Smeđe tlo na } \\
\text { vapnencu } \\
\text { (Kalkokambisol) }\end{array}$ & Tipično & $\begin{array}{c}\text { Plitko } \\
\text { Srednje duboko }\end{array}$ & $\begin{array}{c}\text { Ilovasto } \\
\text { Glinasto }\end{array}$ \\
\hline $\begin{array}{c}\text { Lesivirano ili } \\
\text { ilimerizirano tlo } \\
\text { (Luvisol) }\end{array}$ & Na vapnecima & U vrtači & \\
\hline
\end{tabular}


Tablica 6. Srednje vrijednosti kemijskih i fizičkih karakteristika istraživanih tipova tala

Table 6. Mean values of chemical and physical characteristics of investigated siol types

\begin{tabular}{|c|c|c|c|c|c|c|c|c|c|}
\hline $\begin{array}{c}\text { Tip tla } \\
\text { Soil type }\end{array}$ & \begin{tabular}{|c|} 
Dubina \\
cm \\
Depth \\
\end{tabular} & $\begin{array}{c}\mathrm{pH} \\
\mathbf{u} \\
\mathrm{H}_{2} \mathrm{O} \\
\end{array}$ & $\begin{array}{c}\mathbf{p H} \\
\mathbf{u} \\
\mathrm{n}-\mathrm{KCl} \\
\end{array}$ & $\begin{array}{c}\mathrm{P}_{2} \mathrm{O}_{5} \\
\mathrm{~K}_{2} \mathrm{O} \\
\mathrm{mg} / 100 \text { gr } \\
\end{array}$ & $\begin{array}{c}\text { Humus } \\
\%\end{array}$ & $\begin{array}{c}\text { Ukupni } \\
\text { Total } \\
\text { N\% } \\
\end{array}$ & $\begin{array}{c}\mathrm{C} / \mathrm{N} \\
\%\end{array}$ & $\begin{array}{c}\% \text { Gline } \\
\text { Clays }\end{array}$ & $\begin{array}{l}\text { Tekst. } \\
\text { ozn. } \\
\text { Testure } \\
\end{array}$ \\
\hline $\begin{array}{c}\text { Crnica } \\
\text { (Kalkomelanosol) } \\
\text { na vap. litična } \\
\text { organomineral. } \\
\end{array}$ & $0-22$ & 6,3 & 5,9 & $1,0 \quad 16,7$ & 12,6 & 0,57 & 12,4 & 44,3 & teška glina \\
\hline $\begin{array}{c}\text { Smeđe na vapnencu } \\
\text { (Kalkokambisol) } \\
\text { tipično plitko }\end{array}$ & $\begin{array}{c}2-12 \\
16-32\end{array}$ & $\begin{array}{l}6,5 \\
6,5\end{array}$ & $\begin{array}{l}5,4 \\
5,6\end{array}$ & $\begin{array}{cc}5,3 & 15,0 \\
0,7 & 8,6\end{array}$ & $\begin{array}{c}10,0 \\
7,8\end{array}$ & $\begin{array}{l}0,45 \\
0,32\end{array}$ & $\begin{array}{l}12,9 \\
13,2\end{array}$ & $\begin{array}{l}27,3 \\
52,9\end{array}$ & $\begin{array}{l}\text { laka glina } \\
\text { teška glina }\end{array}$ \\
\hline $\begin{array}{c}\text { Smeđe na vapnencu } \\
\text { (Kalkokambisol) } \\
\text { tipično srednje } \\
\text { duboko } \\
\end{array}$ & $\begin{array}{c}1-15 \\
15-42\end{array}$ & $\begin{array}{l}6,8 \\
6,5\end{array}$ & $\begin{array}{l}6,5 \\
5,7\end{array}$ & $\begin{array}{ll}1,6 & 17,2 \\
1,0 & 10,8\end{array}$ & $\begin{array}{c}10,3 \\
2,4\end{array}$ & $\begin{array}{l}0,36 \\
0,08\end{array}$ & $\begin{array}{l}16,7 \\
17,5\end{array}$ & $\begin{array}{l}36,0 \\
48,0\end{array}$ & $\begin{array}{l}\text { laka glina } \\
\text { teška glina }\end{array}$ \\
\hline $\begin{array}{c}\text { Lesivirano ili } \\
\text { ilimerizirano tlo } \\
\text { (Luvisol) }\end{array}$ & $\begin{array}{c}2-18 \\
18-32 \\
32-84\end{array}$ & $\begin{array}{l}4,9 \\
4,4 \\
7,1\end{array}$ & $\begin{array}{l}4,5 \\
3,7 \\
6,6\end{array}$ & $\begin{array}{ll}2,3 & 28,0 \\
1,0 & 14,2 \\
-\end{array}$ & $\begin{array}{c}6,7 \\
3,0 \\
-\end{array}$ & $\begin{array}{l}0,52 \\
0,26 \\
-\end{array}$ & $\begin{array}{c}13,3 \\
12,4 \\
-\end{array}$ & $\begin{array}{c}33,4 \\
24,3 \\
-\end{array}$ & $\begin{array}{l}\text { laka glina } \\
\text { laka glina } \\
-\end{array}$ \\
\hline
\end{tabular}

Vapnenačko-dolomitna crnica - Calcimelanosol (kalcomelanosol)

(WRB klasifikacija-Leptosol [lithic, hyperskeletic, molic, humic])

Sklop profila Amo-R. Crnica je vezana uz pojavu vapnenaca i dolomita koji imaju više od $98 \% \mathrm{CaCO}_{3}$ odnosno $\mathrm{MgCO}_{3}$. Crnica je primarni razvojni stadij na tom matičnom supstratu. Dominantan je organomineralni podtip i to najčešće $u$ kombinaciji s kalkokambisolom. Struktura tla je sitno mrvičasta. Mehanički sastav je ilovasta glina do glina. Tlo ima visoku poroznost (oko $60 \%$ ), nizak kapacitet zadržavanja vode te jako promjenjivu propusnost. Crnice pod šumskom vegetacijom sadrže humusa $10-40 \%$ i ukupnog dušika 0,3 do $1,3 \%$. Crnica je slabo opskrbljena rastopljivim fosforom, a osrednje rastopljivim kalijem. Ima srednji do visoki kapacitet adsorpcije zasićen bazama u rasponu 50-80 \%. Reakcija je neutralna do kisela. Tla su nepogodna za poljodjelstvo, a marginalno pogodna za ekonomsku šumu.

Smeđe tlo na vapnencu i dolomitu - Cambic soil on limestone and dolomite (kalkokambisol, calcocambisol)

(WRB klasifikacija-Cambisol [leptic, skeletic, humic])

Sklop profila Aoh-(B)rz-R. Pojavljuje se u dva varijeteta, plitko i srednje duboko. Javlja se isključivo na tvrdim čistim vapnencima i dolomitima koji imaju manje od $1 \%$ nerastvorivog ostatka. Maksimalna dubina tla ne prelazi na ovom području $30-70 \mathrm{~cm}$. Veće prodiranje korjenovog sistema u tlo omogućeno je tamo gdje 
je slojanje stijena okomito ili koso. Tla su dobro drenirana samo tamo gdje ima vapnenaca. Debljina humusno akumulativnog horizonta smeđeg tla na dolomitu je prosječno 3-8 cm. Tamnosmeđa boja i praškasta struktura su glavno vizuelno obilježje A horizonta. Leži neposredno na (B)rz horizontu, koji je težeg mehaničkog sastava. Razlog tome je struktura u kambičnom (B)rz horizontu, koja je graškasta do sitno orašasta, a prirodna drenaža je dobra. Ova tla su vrlo humozna zbog svoje količine humusa u A horizontu (10-22\%). Reakcija tla je u rasponu od kisele do neutralne. Ovaj tip tla sadrži malo fosfora i osrednje kalija, a vrlo je bogato dušikom, što ovisi o količini humusa i intenzitetu njegove mineralizacije. Po mehaničkome sastavu tlo je glinasto ilovasto do glinasto, dakle teže tlo.

Lesivirano tlo - Luvisol (ilimerizirano tlo, luvisol)

(WRB klasifikacija-Luvisol [skeletic, humic,])

Sklop profila A-E-B-C. Ova tla imaju specifičan položaj u reljefu. Nalazimo ih u manjim udolinama i donjim dijelovima padina, a naročito na vrtačastim terenima (luvisol u vrtači). Debljina humusnog horizonta je 2-4 cm, s postotkom humusa 6-16 $\%$. U eluvijalnom E horizontu, koji je debljine $25-45 \mathrm{~cm}$, taj postotak može iznositi 3,4-5\%. Reakcija tla je u rasponu od slabo do umjereno kisele. To tlo je srednje opskrbljeno fosforom i kalijem. Po mehaničkome sastavu je glinasta ilovača do laka glina. Luvisoli se formiraju na ilovastim supstratima ili stijenama čijim se raspadanjem može formirati dublji ilovasti profil. Luvisoli su vezani za humidna područja u kojima se mogu formirati descendentni tokovi vode. Za luvisol je karakteristično ispiranje (lesivaža) čestica gline iz E horizonta i njihovo akumuliranje u B horizontu. Eluvijalno-iluvijalna migracija gline odigrava se u uvjetima umjerene kiselosti. Teksturno diferenciranje luvisola često može biti potencirano pritjecanjem eolskog nanosa u površinske slojeve. Eolski proces je naročito intenzivno zahvatio luvisole formirane na vapnencima i dolomitima (dvoslojni profili). Postoji prilično velika razlika između svojstava luvisola formiranih na silikatnim supstratima i na čistim vapnencima i dolomitima. Luvisoli na vapnencima imaju u površinskim slojevima lakšu praškastu teksturu, dok je B horizont najčešće glinovit. Luvisoli imaju normalnu drenažu, $\mathrm{pH}$ je obično u rasponu 5,0 - 6,0 a stupanj zasićenosti bazama ispod $35 \%$. Siromaštvo svim hranjivima u mobilnom obliku vrlo je izrazito.

\section{Zaključak-Conclusion}

Temeljem obavljenih istraživanja strukture sastojine u čistoj bukovoj šumi u rezervatu «Medveđak» na dvije trajne pokusne plohe, i praćenjem brojnosti i kvalitete mladog naraštaja, procjene oštećenosti krošanja, strukture tla te izradbom digitalnog modela projekcije krošanja mogu se donijeti slijedeći zaključci: 
1. Prevelika drvna masa na plohi u Odjelu 61 , od $647,38 \mathrm{~m}^{3}$, temeljnica od 42,67 $\mathrm{m}^{2}$ po ha nagomilana na malom broju stabala (301) odraz je prirodnog tijeka razvoja ovih sastojina.

2. Zastrtost tla krošnjama od $96 \%$ te višestruka zastrtost od $157 \%$ izrazito je važan čimbenik koji je uvjetovao izostanak pojave mladoga naraštaja iz sjemena.

3. Brojnost, kvaliteta i vitalitet mladog naraštaja bukve na promatranoj pokusnoj plohi od 3528 jedinki po hektaru ne osigurava daljnji razvoj očekivanog normalnog procesa prirodne obnove. Naime, većina pomlatka je u visinskom razredu do $30 \mathrm{~cm}(43 \%)$ i do $60 \mathrm{~cm}(39 \%)$ što čini $82 \%$ ukupnih jedinki, a zbog jake zastrtosti tla krošnjama od $96 \%$ upitnog je preživljenja. Nešto prisutniji mladi naraštaj gorskog javora, posebice grmlja, ne ide u prilog prirodnoj obnovi bukve.

4. Rezultati izmjera nultog stanja (1980) i ponovljene izmjere (1988) na plohi u Odjelu 27 ukazuju kako je distribucija prsnih promjera i dalje unimodalnog karaktera desne asimetrije, odnosno distribucija visina kod obje izmjere ukazuje na negativnu skošenost $\left(\beta_{1}=-1.108\right.$ i $\left.-1,511\right)$ i pozitivnu spljoštenost što također ukazuje kako se radi o jednodobnoj sastojini obične bukve. Broj stabala se smanjio za 29 stabala $(6,5 \%)$. Za isti period volumni prirast bukovih stabala $\left(V_{1988}-V_{1980}\right)$ iznosi $60,62 \mathrm{~m}^{3}$, odnosno tečajni godišnji volumni prirast $\left(i_{v}\right)$ iznosi $7,58 \mathrm{~m}^{3}(1,56 \%)$.

5. Prema izmjeri širine krošanja, uz pretpostavku da odumre stablo s najširom krošnjom koja iznosi 14,2 m, otvorio bi se sklop 158,36 $\mathrm{m}^{2}$, što je nedovoljno za razvoj kvalitetnog naraštaja bukve koja po svojoj biologiji zahtijeva obnovu na većim površinama.

6. Rezultati oštećenosti krošanja pokazuju kako je 1998. godine na plohi zabilježeno 5,6\% značajno oštećenih stabala (stabla osutosti krošnje više od $25 \%$ ), dok je takvih stabala u drugom motrenju (2003. godine) bilo tri puta više $(17,1 \%)$. Povećanje značajno oštećenih stabala u 2003. godini valja pripisati velikom udjelu stabala u trećem sloju koja su tijekom svog prirodnog razvoja izlučena u sastojini. Rezultati ukazuju kako kod procjene oštećenosti krošanja treba voditi računa o biološkom položaju stabala u sastojini te da monitoring na ovakvim trajnim pokusnim plohama treba provoditi kontinuirano.

7. Prosječno stanje značajne oštećenosti (stabla osutosti krošnje više od 25\%) obične bukve u Hrvatskoj u posljednjih 9 godina praćenja nije se bitno mijenjalo te se značajna oštećenost kretala od 4,4 do $11,9 \%$ čime je bukva sa $9,5 \%$ u 2003. godini i dalje zadržala epitet najotpornije vrste drveća u Hrvatskoj.

8. U pedološkom smislu područje je nehomogeno jer je zastupljeno s više tipova tala. Tla su različitih proizvodnih sposobnosti što prvenstveno ovisi o njihovoj dubini, mehaničkome sastavu, opskrbljenosti hranjivima i sadržaju vlage u tlu. Najproizvodnija su tla u predjelu vrtača (luvisoli), zatim smeđa tla na 
vapnencima (kalkokambisoli) i na kraju crnice na vapnencima (kalkomelanosoli).

9. Istraživanja koja se provode na obje plohe su osnova za dugotrajna multidisciplinarna promatranja kretanja prirodnog tijeka razvoja strukturnih promjena u sastojinama obične bukve prašumskoga tipa prema programima znanstvenih istraživanja Šumarskog instituta, Jastrebarsko i Šumarskog fakulteta Sveučilišta u Zagrebu.

\section{Literatura-References}

1. CESTAR D., V. HREN, Z. KOVAČEVIĆ. J. MARTINOVIĆ, Z. PELCER 1976: Ekološko-gospodarski tipovi šuma na području Nacionalnog parka Plitvička jezera. Rad. Šumar. inst. 28: 1-87, Zagreb.

2. CESTAR D., V. HREN, Z. KOVAČEVIĆ, J. MARTINOVIĆ, Z. PELCER, K.BEZAK, A. KRZNAR, V. LINDIĆ, B. VRBEK, V. KREJČl 1982: Prirodni šumski rezervat Medveđak. Rad. Šumar. inst. 50:1-76, Zagreb.

3. CESTAR D., V. HREN, Z. KOVAČEVIĆ, J. MARTINOVIĆ, Z. PELCER, K.BEZAK, V. KREJČI, A. KRZNAR, V. LINDIĆ, J. MEDVEDOVIĆ, B. VRBEK 1983: Prirodni šumski rezervat Čorkova uvala-Čudinka. Rad. Šumar. inst. 53:1-44, Zagreb.

4. CESTAR D., V. HREN, Z. KOVAČEVIĆ, J. MARTINOVIĆ , Z. PELCER, K.BEZAK, V. KREJČI, A. KRZNAR, V. LINDIĆ, J. MEDVEDOVIĆ , B. VRBEK 1984: Prirodni šumski rezervat Rječica-Javornik. Rad. Šumar. inst. 58:41-76, Zagreb.

5. CESTAR D., V. HREN, Z. KOVAČEVIĆ, J. MARTINOVIĆ, Z. PELCER 1986: Uputstva za izradu karte ekološko-gospodarskih tipova gorskog područja (I) SR Hrvatske. Rad. Šumar. inst. izvanredno izdanje 4: 1-125, Zagreb.

6. DUBRAVAC, T., V. NOVOTNY, 1992: Metodologija tematskog područja uzgajanje šuma - rast i prirast (primijenjena u multidisciplinarnom projektu ekološko ekonomske valencije tipova šuma). Rad. Šumar. inst. 27 (2): 157-166, Jastrebarsko.

7. DUBRAVAC, T., 2002: Zakonitosti razvoja strukture krošanja hrasta lužnjaka i običnoga graba ovisno o prsnom promjeru i dobi u zajednici «Carpino betuliQuercetum roboris Anić em Rauš 1969». Disertacija pp 196, Zagreb.

8. DUBRAVAC, T., BENKO, M, ČAVLOVIĆ, J. 2003: Application of digitalisation in studying the structure of uneven-aged stands in non-economic forests of Croatia. IUFRO Internacionalni Interdisciplinary Conference and Field Tour, «Uneven-aged Forest Management: Alternative Forms, Practises, and Constraints» Finland and Sweden, june 8-17, 2003., pages 5 (usmeno izlaganje).

9. DUBRAVAC. T., D. VULETIĆ, 2003: Aktivna ili pasivna zaštita šumaprimjer nacionalni park Risnjak. 8. Hrvatski biološki kongres s međunarodnim 
sudjelovanjem, 27 rujna do 2. listopada 2003., usmeno izlaganje, Zbornik, 394395, Zagreb.

10. HREN, V., 1972: Ramino korito-prašuma bukve. Šum. list, 96 9/10: 315-324, Zagreb.

11. KLEPAC, D., 1984: Principi uređivanja šuma Nacionalnog Parka "Plitvička jezera". Šum. list 7/8:319-335, Zagreb.

12. KLEPAC, D., 1994: Ekološko uređivanja šuma u Nacionalnom Parku "Plitvička jezera". Plitvička jezera nacionalno dobro Hrvatska svjetska baština: 69-80.

13. KREJČI, V., T. DUBRAVAC, 2001: Mogućnost obnove šuma Nacionalnih parkova. Rad. Šumar. inst. 36 (2): 113-122, Jastrebarsko.

14. KREJČI, V., T. DUBRAVAC, 2003: Mogućnost i opravdanost oplodnih sječa u bukovim šumama Gorskog kotara, Like i Hrvatskog primorja. Šum. list 9/10:449-456, Zagreb.

15. LUKIĆ, N., T. KRUŽIĆ, 1992: Razvoj obične bukve (Fagus sylvatica L.) na trajnoj plohi Medveđak. Šum. list 11/12, 510-513, Zagreb.

16. MATIĆ, S., M. ORŠANIĆ, I. ANIĆ, 1995: Strukturne osobine šuma otoka Mljeta. Prirodne značajke i društvena revitalizacija otoka Mljeta (simpozij), 297-303.

17. MATIĆ, S., M. ORŠANIĆ, I. ANIĆ, 1996: Bukove šume Hrvatske i njihovo mjesto u kompleksu šuma središnje i jugoistočne Europe. Znanstvena knjiga: B. Mayer (ur), Unapređenje proizvodnje biomase šumskih ekosustava, Šumarski fakultet Sveučilišta u Zagrebu i Šumarski institut, Jastrebarsko, str. 113-124, Zagreb.

18. POŠTENJAK, K., M. GRADEČKI M, 1994: Stojbinske prilike šuma N.P. "Risnjak". Zbornik Radova, Crni lug, 34-46, Crni Lug.

19. SCHOBER, R., 1972: Rotbuche 1971. J.D. Sauerländer's V., Frankfurt, 333 $\mathrm{pp}+\mathrm{A} 112$.

*** 2003: Obična bukva u Hrvatskoj. Monografija. Akademija šumarskih znanosti, «Hrvatske šume» d.o.o., Zagreb, Grad Zagreb, Gradski ured za poljoprivredu i šumarstvo, Zagreb.

*** 1993: Zaštita i očuvanje Europskih šuma. Ministarstvo poljoprivrede i šumarstva i J.P. «Hrvatske šume» p.o., Zagreb.

*** http://www.mzopu.hr

\section{SUMMARY}

Beech forests are spread over an area of 1100000 ha, which amounts to $56.5 \%$ of the area of forests in Croatia. Pure beech forests are spread over 250000 ha, beech forests with mixed Sessile-flowered oak over 700000 ha, and mixed forests of beech and fir cover an area of 165000 ha. Of the total area of beech forests $85 \%$ are high silvicultural form forests, developed from seed, and the remaining $15 \%$ are forests of low silvicultural type or coppice forests. Natural regeneration by seed tree 
cuttings on small areas with a longer regeneration period is the optimal method of reforestation for these forests, where, together with appropriate tending of the forest, general benefits and management functions are fully expressed (Matić et al, 1996). The latest investigation (Krejči and Dubravac 2003) indicates the justifiability of applying even-aged method of management by seed tree cuttings in pure beech stands.

The paper presents the results of investigations of the condition of the structure and possibility of natural regeneration of pure beech stands in a secondary virgin forest of beech in the forest reservation "Medveđak". The reservation is located within a large forest complex of beech forests in the northeastern part of the Plitvice Lakes National Park. The investigations were carried out in a natural stand of mountain beech forest with dead nettle (Lamio orvale-Fagetum sylvaticae Ht. 1938). The reservation was established by the Department of Forest Typology, Forest Research Institute Jastrebarsko in 1976, on an area of 156.3 ha, covering three compartments $(26,27$ and 61). The investigations were performed on two permanent experimental plots, 1 ha in size. The first plot was established in 1980 by the Faculty of Forestry University of Zagreb within the framework of the Project "One hundred permanent plots in the Republic of Croatia", and the second by the Forest Research Institute Jastrebarsko in 1998, within the framework of the Project "Growth and development of the forests for specific assignment".

On the plot established by the Forest Research Institute Jastrebarsko all trees larger than $7.5 \mathrm{~cm}$ in diameter were numbered and basic estimation data recorded $(\mathrm{d} \mathrm{b}$ $\mathrm{h}$, tree height and length of stems) on the basis of which basic structural indicators were calculated (number of trees, basal area and volume). A sub-plot of $60 \times 60 \mathrm{~m}$ was established in the most homogeneous part of the plot. Horizontal projections of crowns were recorded for all trees on the basis of which calculations were made of the sum of crown projections per ha in absolute and relative size, soil not covered by crowns, mean projection and mean crown diameter. A digital dynamic model of crown projections and vertical stand profile were produced. For the purpose of monitoring the possibility of natural reforestation on the sub-plot, the structure and number of young growth was recorded, including the shrub layer, on an area of $360 \mathrm{~m}^{2}$ (three strips of $2 \times 60 \mathrm{~m}$ ), and classified into height-age classes. Estimation of crown damage was performed by the method prescribed by the International Programme for Estimation and Monitoring of Air Pollution for Forests (ICP Forests).

Results indicate an excessive volume of wood of $647.38 \mathrm{~m}^{3}$, basal area of $42.67 \mathrm{~m}^{2}$ per ha accumulated on a small number of trees (301), which reflects the natural development course of these stands. The number, quality and vitality of beech young growth on the observed experimental plot of 3528 plants per hectare, do not guarantee further development of the expected normal process of natural reforestation. Namely, the majority of young growth is in the height class up to $30 \mathrm{~cm}(43 \%)$ and up to $60 \mathrm{~cm}(39 \%)$ amounting to $82 \%$ of the overall number of plants, and due to the heavy density of canopy cover over soil of $96 \%$, survival is questionable. Somewhat increasingly more present sycamore young growth, in particular shrubs, is unfavourable for beech natural reforestation. According to the measurements of crown 
widths from the digital model of horizontal crown projections, on the assumption that the tree with the widest crown dies, which amounts to $14.2 \mathrm{~m}$, a canopy of $158.36 \mathrm{~m}^{2}$ would be opened. (Table 1), which is insufficient for the development of high-quality new growth of beech, which according to its biology requires reforestation on larger areas.

The results of the tree-crown damage show that in 1998 there were $5.6 \%$ considerably damaged trees (damage of over $25 \%$ ), while there were three times more $(17.1 \%)$ trees with such damage during the second observation (2003). The increase in considerably damaged trees in 2003 can be attributed to the great share of trees in the third layer which, during their natural development, were isolated in the stand. Results show that when estimating damage in tree crowns the biological position of the trees in the stand should be taken into account, and that monitoring on such permanent experimental plots should be of a continuous character. The average state of significant damage (crown defoliation more than 25\%) for Common beech in Croatia during the last 9 years of monitoring has not changed essentially; significant damage ranged from $4.4-11.9 \%$, and for beech it was $9.5 \%$ in 2003 and continued to retain the name of the most resistant tree species in Croatia.

Measurement results of zero state (1980) and repeated measurements (1988) on the plot in Compartment 27, established by the Faculty of Forestry University of Zagreb, indicate that the distribution of $\mathrm{d} \mathrm{b} \mathrm{h}$ continues to be of uni-model character of right symmetry. Namely, distribution of heights in both measurements indicates a negative "skošenost" ( leaning, tilting) $\left(\beta_{1}=-1.108\right.$ and - 1.511) and positive "spljoštenost" (damping off, flatness), which also shows that it is an even-aged stand of Common beech. The number of trees decreased by 29 trees $(6.5 \%)$. The volume increment of beech trees $\left(V_{1988}-V_{1980}\right)$ for the same period amounted to $60.60 \mathrm{~m}^{3}$. Namely, current annual increment in volume $\left(i_{v}\right)$ amounted $7.58 \mathrm{~m}^{3}(1.56 \%)$.

Pedologically the region is inhomogeneous because it includes various types of soil. The soils are of different productive potentials, which primarily depend on their depth, mechanical composition, nutrients and content of moisture in the soil. The most productive soils are in the region of sink-holes (luvisols), followed by calcicambisols and finally calcimelanosols.

Investigations which are carried out on both plots are the basis for long-term multidisciplinary monitoring of the progression of the natural course of development of structural changes in Common beech stands of virgin type, in accordance with the scientific research plans of the Forest Research Institute Jastrebarsko and the Faculty of Forestry, University of Zagreb. 